\title{
SCREEN HOUSE TEST OF EIGHT BIOPESTICIDE FORMULATION Bacillus subtilis AGAINST DOWNY MILDEW, Peronosclerospora philipinensis, ON CORN PLANT
}

\author{
Nurasiah Djaenuddin, Amran Muis, \& Nurnina Nonci \\ Indonesian Cereals Research Institute \\ Jl. Dr. Ratulangi No. 274 Maros 90514 \\ Email: asiahdjaenuddin@gmail.com
}

\begin{abstract}
Screen house test of eight biopesticide formulation Bacillus subtilis against downy mildew, Peronosclerospora philipinensis, on corn plant. Corn downy mildew (DM) caused by Peronosclerospora spp. is a major constraint to the decline in maize production because it can cause yield loss up to $100 \%$. So far, DM was successfully controlled with metalxyl fungicide. But lately, the effectiveness of this fungicide has begun to decline, so there is a need for an appropriate and environmentally friendly control alternative, one of which is the use of biological control agents. The aim of this study was to know the influence of eight types of biopesticide formulation of Bacillus subtilis in controlling DM of corn plant. The study was conducted at the screenhouse of the Indonesian Cereals Research Institute at Maros from November to December 2016. The treatments were arranged in a randomized block design with nine treatments and three replications. The treatment consisted of seed treatment with eight types of B. subtilis formulations (TM4, TM3, BNt4, BNt5, BNt6, BNt8, BJ6, and TLB1) and one treatment with sterile water (control). The variety used was Anoman which is known to be highly susceptible to DM. The variables observed included number of germination, the incidence and incubation period of disease, plant height, and dry weight of the plant. The results showed that the eight $B$. subtilis formulations had the potential to suppress DM in corn. The symptom of DM began to be seen at 18 days after planting (DAP) on the treatment of BNt8, while the controls have been seen at 12 HST. B. subtilis TM formulation has the highest potential to suppress DM with the percentage of disease suppression reaching $63.1 \%$.
\end{abstract}

Key words: biological control agent (BCA), natural inoculation, seed treatment

\begin{abstract}
ABSTRAK
Pengujian rumah kawat delapan formulasi biopestisida Bacillus subtilis terhadap penyakit bulai Peronosclerospora philipinensis pada tanaman jagung. Penyakit bulai yang disebabkan oleh Peronosclerospora spp. merupakan kendala utama penurunan produksi jagung karena dapat menyebabkan kehilangan hasil hingga $100 \%$. Selama ini bulai berhasil dikendalikan dengan fungisida metalksil. Namun akhir-akhir ini, keefektifan fungisida tersebut sudah mulai menurun sehingga diperlukan alternatif pengendalian yang tepat dan ramah lingkungan, salah satunya adalah penggunaan agens pengendali hayati. Penelitian bertujuan untuk mengetahui pengaruh delapan jenis formulasi biopestisida Bacillus subtilis dalam mengendalikan penyakit bulai P. philipinensis pada tanaman jagung. Penelitian dilaksanakan di rumah kawat Balai Penelitian Tanaman Serealia, Maros dari November sampai Desember 2016. Perlakuan disusun dalam rancangan acak kelompok dengan sembilan perlakuan dan tiga ulangan. Perlakuan terdiri atas perlakuan benih dengan delapan jenis formulasi biopestisida $B$. subtilis (TM4, TM3, BNt4, BNt5, BNt6, BNt8, BJ6, dan TLB1) dan satu perlakuan dengan air steril (kontrol). Varietas yang digunakan adalah Anoman yang dikenal sangat rentan terhadap bulai. Variabel pengamatan meliputi jumlah tanaman tumbuh, persentase serangan dan masa inkubasi penyakit, tinggi tanaman, dan bobot kering tanaman. Hasil penelitian menunjukkan bahwa kedelapan jenis formulasi $B$. subtilis memiliki potensi menekan penyakit bulai pada tanaman jagung. Gejala penyakit bulai baru nampak terlihat pada 18 hari setelah tanam (HST) pada perlakuan BNt8, sedangkan pada kontrol sudah terlihat pada 12 HST. Formulasi B. subtilis TM4 memiliki potensi yang paling tinggi untuk menekan penyakit bulai dengan persentase penekanan penyakit mencapai $63,1 \%$.
\end{abstract}

Kata kunci: agens pengendali hayati, inokulasi alami, perlakuan benih 


\section{INTRODUCTION}

Corn has an important and strategic role in maintaining food security, therefore it is necessary to increase domestic corn production (Fahmi \& Sujitno, 2015). Aside from being a source of protein, corn is also used as animal feed ingredients. However, the productivity of corn cultivated by farmers still varies in several areas of corn production areas in Indonesia (Pakki \& Burhanuddin, 2013). One of the causes of the low production of corn is due to the incidence of pests and diseases (Soenartiningsih et al., 2008). However, according to Sujiprihati et al. (2012) who assembled hybrid corn varieties with high yield and resistance to downy mildew that there were five sweet corn lines showed resistant to downy mildew with the incidence ranging from 0.0 to $7.0 \%$. Corn downy mildew disease caused by Peronosclerospora spp. is a major problem in increasing corn production in Indonesia because it can cause yield loss up to $100 \%$ (Rustiani, 2015). The high incidence of downy mildew can result in a decrease in corn production both in terms of quantity and quality, even in severe incidence it can cause crop losses (Talanca \& Tenrirawe, 2015).

The control method used so far is the treatment of seeds with metallaxill fungicides (Muis et al., 2013). The ineffectiveness of the use of metallaxill fungicides on downy mildew on maize in several places in Indonesia raises speculation that there are genetic variations in species of Peronosclerospora in Indonesia (Lukman et al., 2013). P. philipinensis was only found on the island of Sulawesi, while P. maydis and P. sorghi were found in almost all islands in Indonesia (Muis et al., 2016). Corn seeds circulating in Indonesia both hybrid and open pollinate have all been treated with metallaxyl fungicide. Pesticide application continuously for a long time can cause resistance to plant pest organisms (Burhanuddin, 2009). For this reason, an alternative control method against downy mildew is needed.

The use of biological control agents is one of the control methods against downy mildew that safe for consumers and the environment. It has been reported by Sadoma et al. (2011) that the application of Trichoderma viride, T. harzianum, Gliocladium virens, and Bacillus subtilis singly and in combination has positive interactions with each other in suppressing the development of $P$. sorghi. The application of endophytic fungi as a biopesticide agent has been reported by Amin et al. (2013) that the treatment of Beauveria sp. isolates effective to control downy mildew Peronosclerospora spp. In other tests, the application of Bacillus sp. and Pseudomonas sp. were able to suppress the development of downy mildew caused by P. maydis with the highest emphasis on Pseudomonas sp. UB-PF5 was 50\% (Jatnika et al., 2013). The use of Plant Growth Promoting Rhizobacteria (PGPR) $B$. subtilis UB-ABS 4 and 5 can suppress incidence of downy mildew Peronosclerospora spp. up to 50\% (Zainudin et al., 2014).

This study aims to determine the effect of eight isolates of B. subtilis biopesticide formulations in controlling downy mildew caused $P$. philipinensis.

\section{MATERIALS AND METHODS}

Research Site. This research was carried out in the screen house of the Indonesian Cereals Research Institute at Maros from November to December 2016. The seeds used were Anoman variety. The treatments were arranged in a randomized block design with nine treatments and three replications. The treatment consists of eight biopesticide formulations that were distinguished based on the location of the isolates collected in several districts of South Sulawesi and one isolate collected from South Kalimantan i.e. B. subtilis TM4 (location 4 Malino, Gowa), TM3 (location 3 Malino, Gowa), BNt4 (location 4 Bone), BNt5 (location 5 Bone), BNt6 (location 6 Bone), BNt8 (location 8 Bone), BJ6 (location Bajeng, Gowa), and TLB1 (location Bati-Bati, Tanah Laut, South Kalimantan) and sterilized distilled water as control treatment.

Seed Treatment. Two hours before planting, the seeds were treated by mixing $3 \mathrm{~g}$ of $B$. subtilis formulation with a concentration of $10^{9} \mathrm{cfu} \mathrm{g}^{-1}$ with $100 \mathrm{~g}$ of corn seeds, then air dried.

Planting. Seeds were planted in the screen house that already has source inoculum of downy mildew. Plot size was $5 \times 6 \mathrm{~m}$, planting space was $75 \times 25 \mathrm{~cm}$, one seed per hole. Fertilization was given 10 days after planting by applying Phonska with the dose of $300 \mathrm{~kg} \mathrm{ha}^{-1}$.

Observation and Data Collection. Observations were carried out every day for three weeks to determine the incubation period for downy mildew. Other variables observed were disease incidence, plant height, and dry weight of corn plants. Percentage of disease incidence were calculated by the formula:

Disease Incidence $=\frac{\text { Number of infected plant }}{\text { Number of plant observed }} \times 100 \%$ 
Experimental Design and Data Analysis. Treatments were arrange in randomized completely block design with 9 treatments and 3 replicates. Data were analyzed using variance and continued with the Tukey test at a significant level of $5 \%$.

\section{RESULTS AND DISCUSSION}

In general, eight biopesticide formulations of $B$. subtilis have the best effect on the growth and on the dry weight of plants (Table 1). If the TM4 formulation gives the best effect on the plant growth (100\%) and dry weight $(2.1 \mathrm{~kg})$, then the BNt8 formulation treatment shows the incubation period of downy mildew was 18 days which was slower than other treatments (Table 2).

Statistically, the incidence of downy mildew in all treatments was not significantly different, except for TM4 treatment starting 4-5 weeks after planting (WAP). The lowest percentage of downy mildew incidence until the end of the observation occurred in the formulation treatment of B. subtilis TM4 at 54.4\% (Figure 1). The results of this study are almost the same as the results obtained by Hoerussalam et al. (2013) which concluded that the use of Plant Growth Promoting Rhizobacteria (PGPR) Bio1 and Bio2 can induce corn plant resistance to downy mildew through seed treatment. The use of bacterial inoculant as a seed treatment has also been reported to be able to increase cob weight per plant, growth speed and germination of seed and reduce the incidence of downy mildew on sweet corn (Sonhaji et al., 2013).

Eight biopesticide formulations of $B$. subtilis have the ability to suppress the development of $P$. philipinensis in corn plants with a percentage of disease suppression of $5.3 \%$ to $63.1 \%$ (Figure 2). The highest suppression of downy mildew incidence was shown by the formulation of B. subtilis TM4 with $63.1 \%$. It was suspected that the location of soil sampling for TM4 isolates is an extreme type of soil, thus allowing microbes obtained from the soil to have a better antibiotic inhibitory mechanism than isolates obtained from ordinary soil. According to Suriani \& Muis (2016) antagonist bacteria B. subtilis not only inhibits conidia germination and appressoria formation, but also inhibits haustoria development and fungal mycelia elongation through the mechanism of production of antibiotic compounds. Awais et al. (2010) suggested that the main antibiotics produced by $B$. subtilis included polymyxin, difisidine, subtilin, mycobacillin, and bacitracin.

The role of formulation of $B$. subtilis in the growth of corn plants is shown in the results of observations of plant height and dry weight of corn plants. In general, plant height in the treatment formulation of $B$. subtilis was better than the control (Table 2). Application of formulation of B. subtilis has an effect on plant height, the formulation application has an average plant height between $70-103.5 \mathrm{~cm}$, while in the control, the plant height reaches only $59.7 \mathrm{~cm}$. This is thought to be related to the low intensity of disease attack in the treatment of B. subtilis formulation, in accordance with the results of the study of Asputri et al. (2013) that the incidence of downy mildew can affect plant growth. In addition, B. subtilis is an PGPR which has an effect on directly producing plant growth hormones. Zongzheng et al. (2009) reported that inoculation B. subtilis SY1 had a large effect in shortening germination time, increasing shoot index, and promoting radical growth and embryo in plant nursery.

Table 1. The effect of eight biopesticide formulations of $B$. subtilis on plant height and dry weight of corn plant

\begin{tabular}{lcccc}
\hline \multirow{2}{*}{ Treatments } & \multicolumn{2}{c}{ Plant height $(\mathrm{cm})$} & & Dry weight of plant $(\mathrm{kg})$ \\
\cline { 2 - 3 } & 2 WAP & 5 WAP & 6 WAP \\
\hline B. subtilis TM4 & 52.0 & 103.5 & 2.1 \\
B. subtilis TM3 & 53.0 & 85.9 & 2.0 \\
B. subtilis BNt4 & 53.3 & 75.9 & 1.4 \\
B. subtilis BNt5 & 51.6 & 87.9 & 1.6 \\
B. subtilis BNt6 & 49.0 & 70.5 & 1.3 \\
B. subtilis BNt8 & 53.1 & 70.0 & 1.2 \\
B. subtilis BJ6 & 51.8 & 73.4 & 1.3 \\
B. subtilis TLB1 & 51.5 & 79.8 & 1.5 \\
Control & 45.8 & 59.7 & 1.0 \\
\hline
\end{tabular}




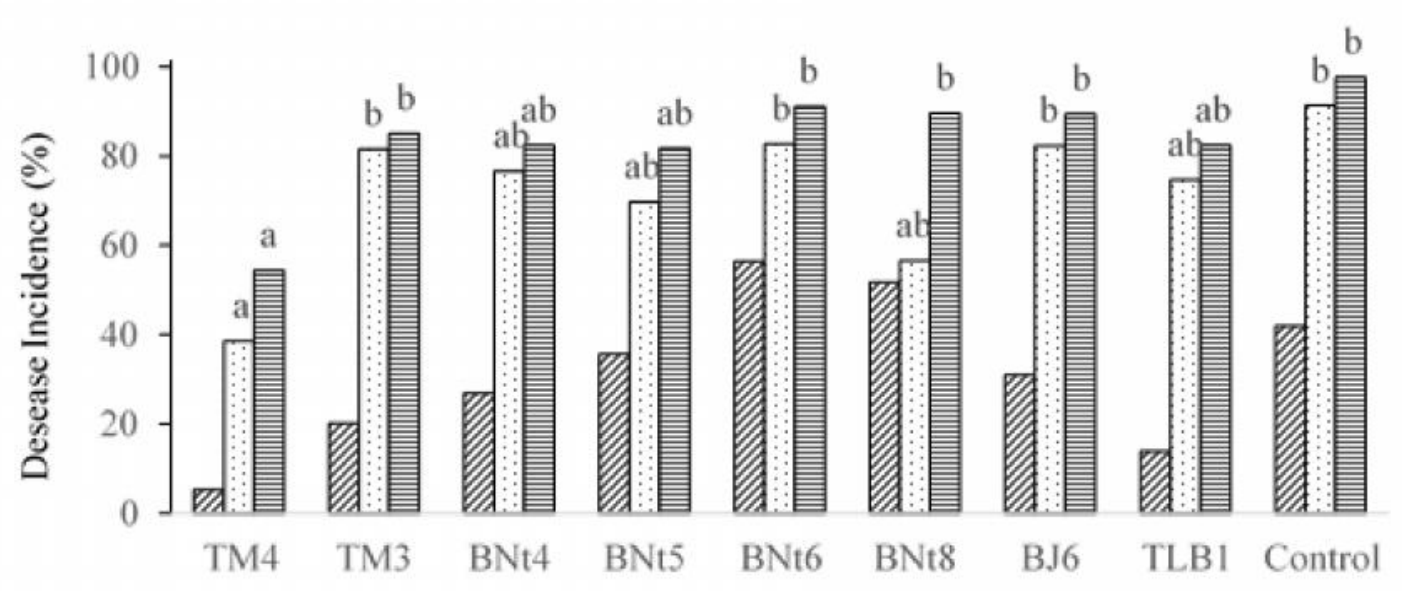

Treatment

\section{WAP $\square 4$ WAP 目 5 WAP}

Figure 1. The development of downy mildew for three observations in various treatments (bars of the same color and followed by the same letter are not significantly different according to the Tukey test of 5\%).

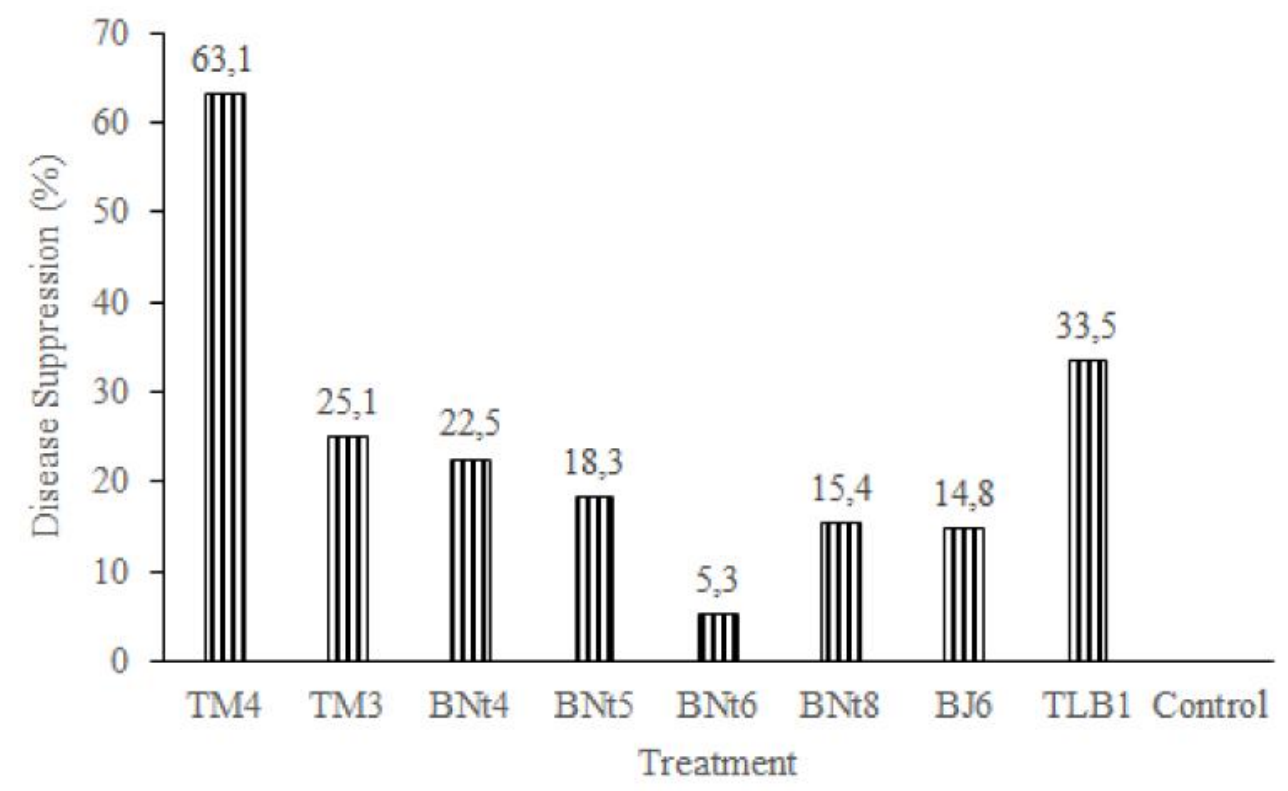

Figure 2. Percentage of suppression of downy mildew in various treatments. 
Table 2. The effect of eight B. subtilis formulations against percentage of plant growth and incubation period of downy mildew

\begin{tabular}{lcc}
\hline Treatments & Germination (\%) At 7 DAP & Incubation period (day) \\
\hline B. subtilis TM4 & 100 & $15 \mathrm{~b}$ \\
B. subtilis TM3 & 93 & $15 \mathrm{~b}$ \\
B. subtilis BNt4 & 91 & $15 \mathrm{~b}$ \\
B. subtilis BNt5 & 88 & $17 \mathrm{ab}$ \\
B. subtilis BNt6 & 82 & $12 \mathrm{c}$ \\
B. subtilis BNt8 & 86 & $18 \mathrm{a}$ \\
B. subtilis BJ6 & 88 & $12 \mathrm{c}$ \\
B. subtilis TLB1 & 84 & $17 \mathrm{ab}$ \\
Control & 84 & $12 \mathrm{c}$ \\
\hline Coefisien of Variation & $12.8 \%$ & $6.4 \%$ \\
\hline
\end{tabular}

Numbers in the same column and followed by the same letters are not significantly different based on Turkey test at $5 \%$ significant level.

Disease incidence that tends to be lower in the treatment of seeds with formulation of $B$. subtilis when compared to controls is thought to contribute positively to the dry weight of plants (Table 2). The dry weight of plants in the treatment of $B$. subtilis formulation reached $1.2 \mathrm{~kg}$ to $2.1 \mathrm{~kg}$, whereas in the control treatment only weighed $1.0 \mathrm{~kg}$. The use of bacterial inoculants as seed treatment has also been reported to be able to produce a better vigor index and growth speed than the control treatment on sweet corn seeds (Sonhaji et al., 2013). This is supported by the results of a study by Utomo et $a l$. (2010) that higher crop production is associated with lower rates of downy mildew, lower leaf chlorosis, and higher photosynthesis ability.

\section{CONCLUSION}

The biopesticide formulation of B. subtilis has the potential to suppress downy mildew incidence on corn. The formulation of B. subtilis TM4 has the highest potential to suppress downy mildew with a percentage of disease suppression of $63.1 \%$ and is also able to delay the incubation period up to 7 DAP.

\section{ACKNOWLEDGMENTS}

We thank to Mrs. Amina and Mr. Hasbi for their excelent technical assistance in laboratory and field.

\section{REFERENCES}

Amin N, Daha L, Nasruddin A, Junaed M, \& Iqbal A. 2013. The use of endophytic fungi as biopesticide against downy mildew Peronosclerospora spp. on maize. Academic Research International 4(4): 153-159.

Asputri NU, Aini LQ, \& Abadi AL. 2013. Pengaruh aplikasi Pyraclostrobin terhadap serangan penyebab penyakit bulai pada lima varietas jagung (Zea mays). J. HPT 1(3): 77-84.

Awais M, Pervez A, Yaqub A, \& Shah MM. 2010. Production of antimicrobial metabolites by Bacillus subtilis immobilized in Polyacrymilade gel. Pak. J. Zool. 42(3): 267-275.

Burhanuddin. 2009. Fungisida metalaksil tidak efektif menekan penyakit bulai (Peronosclerospora maydis) di Kalimantan Barat dan alternatif pengendaliannya. Prosiding Seminar Nasional Serealia. Hlm. 395-399. Maros, July 29, 2009. Balai Penelitian Tanaman Serealia.

Fahmi T \& Sujitno E. 2015. Keragaan produktivitas varietas jagung pada musim hujan di lahan kering dataran tinggi Kabupaten Bandung, Jawa Barat. Pros. Sem. Masy. Biodiv. Indon. 1(7): 16741677. 
Hoerussalam, Purwantoro A, \& Khaeruni A. 2013. Induksi ketahanan tanaman jagung (Zea mays L.) terhadap penyakit bulai melalui seed treatment serta pewarisannya pada generasi S1. Ilmu Pertanian 16(2): 42-59.

Jatnika W, Abadi AL, \& Aini LQ. 2013. Pengaruh aplikasi Bacillus sp. dan Pseudomonas sp. terhadap perkembangan penyakit bulai yang disebabkan oleh jamur patogen Peronosclerospora maydis pada tanaman jagung. Jurnal HPT 1(4): 19-29.

Lukman R, Afifuddin A, \& Lubberstedt T. 2013. Unraveling the genetic diversity of maize downy mildew in Indonesia. J. Plant Pathol. Microbiol. 4(2): $1-8$.

Muis A, Pabendon MB, Nonci N, \& Waskito WP. 2013. Keragaman genetik Peronosclerospora maydis penyebab bulai pada jagung berdasarkan analisis marka SSR. Jurnal Penelitian Pertanian Tanaman Pangan 32(3): 139-147.

Muis A, Nonci N, \& Pabendon MB. 2016. Geographical distribution of Peronosclerospora spp., the causal organism of maize downy mildew, in Indonesia. AAB Bioflux 8(3): 143-155.

Pakki S \& Burhanuddin. 2013. Peranan varietas dan fungisida dalam dinamika penularan patogen obligat parasit dan saprofit pada tanaman jagung. Prosiding Seminar Nasional Serealia. Maros June 18, 2013. Balai Penelitian Tanaman Serealia.

Rustiani US. 2015. Keragaman dan Pemetaan Penyebab Penyakit Bulai Jagung di 13 Provinsi Indonesia. Disertasi. Institut Pertanian Bogor. Bogor.

Sadoma MT, El-Sayed ABB, \& El-Moghazy MM. 2011. Biological control of downy mildew diseases of maize caused by Peronosclerospora sorghi using certain biocontrol agents alone or in combination. J. Agr. Res. 37(1): 1-11.
Soenartiningsih, Talanca AH, Juniarsih, \& Yasin HG. 2008. Pengujian beberapa varietas/galur jagung terhadap penyakit busuk pelepah dan bulai. Prosiding Seminar Ilmiah dan Tahunan PEIPFI XIX Komda Sulsel. Makassar.

Sonhaji MY, Surahman M, Ilyas S, \& Giyanto. 2013. Perlakuan benih untuk meningkatkan mutu dan produksi benih serta mengendalikan penyakit bulai pada jagung manis. J. Agron. Indones. 41(3): 242-248.

Sujiprihati S, Syukur M, Makkulawu AT, \& Iriany RN. 2012. Perakitan varietas hibrida jagung manis berdaya hasil tinggi dan tahan terhadap penyakit bulai. JIPI 17(3): 159-165.

Suriani \& Muis A. 2016. Prospek Bacillus subtilis sebagai agen pengendali hayati patogen tular tanah pada tanaman jagung. J. Litbang Pert. 35(1): 37-45.

Talanca AH \& Tenrirawe A. 2015. Respon beberapa varietas terhadap penyakit utama jagung di Kabupaten Kediri Jawa Timur. Jurnal Agrotan. 1(1): 67-78.

Utomo SD, Islamika N, Ratih S, \& Ginting C. 2010. Pengaruh fungisida metalaksil-M terhadap keterjadian penyakit bulai dan produksi populasi jagung lagaligo $\mathrm{X}$ tom thumb. Jurnal Agrotropika 15(2): 56-59.

Zainudin, Abadi AL, \& Aini LQ. 2014. Pengaruh pemberian Plant Growth Promoting Rhizobacteria (Bacillus subtilis dan Pseudomonas fluorescens) terhadap penyakit bulai pada tanaman jagung (Zea mays L.). Jurnal HPT 2(1): 11-18.

Zongzheng Y, Xin L, Zhong L, Jinzhao P, Jin Q, \& Wenyan Y. 2009. Effect of Bacillus subtilis SY1 on antifungal activity and plant growth. Int. J. Agric. Biol. Eng. 2(4): 55-61. 